\title{
Is the spectre of Weimar still haunting?: 'Militant democracy' and party proscription in contemporary Germany
}

\begin{abstract}
The way in which democratic states react to political parties with antidemocratic goals is a subject of major interest and debate in the study of political extremism. Previous authors have coined the term 'militant democracy' for states that employ severe restrictions against extremist parties. In this regard, Germany is widely perceived as the prototype of a 'militant democracy'. The so-called 'wehrhafte Demokratie' scheme within the Basic Law consists of provisions such as Art. 21(2), providing the possibility of banning a party. However, recent developments in the German practice of party-banning challenge the outright classification of Germany as a 'militant democracy'. Based on a case study of the failed attempt to ban the extreme-right party NPD, this study investigates the question as to what extent the 'wehrhafte Demokratie' scheme in Germany can still be characterised as militant in application. It claims that the 2017 judgment of the Federal Constitutional Court represents a paradigm shift in German party-banning, calling for a reclassification of Germany as an 'immunised democracy'. The Court has moved towards a more cautious and restrictive interpretation of Art. 21(2), displaying an increasing trust in the German democratic system to contain its enemies without having to employ its sharpest legal weapons.
\end{abstract}

\section{Franca Feisel ${ }^{1}$}

\footnotetext{
${ }^{1}$ Franca Feisel received a Bachelor degree in European Studies from Maastricht
} University in 2017. Contact: franca.feisel@gmail.com. 


\section{Introduction}

"This will always remain one of the best jokes of democracy that it gave its deadly enemies the means by which it was destroyed" (Goebbels, cited in Cram, 2008, p. 77) - this sarcastic statement by the propaganda minister of the National-Socialist NSDAP in the wake of Hitler's rise to power continues to reflect one of the most fundamental paradoxes in democratic theory and practice. While liberal principles such as tolerance, free speech and free elections represent the cornerstones of a democratic system, they also entail the possibility that illiberal views can take control of democratic institutions via legal routes. In this context, it is particularly controversial how far a system can go in fighting its enemies without compromising core democratic principles. Is a democracy obliged to 'tolerate the intolerant'?

In political philosophy, the answer to this question depends on the underlying conception of democracy. According to the 'procedural' view, democracy represents a mere method of government formation through free and fair elections. All political views, including extremist ones, are equally entitled to compete on the "free market-place of ideas" (Cram, 2008, p. 76). This conception accepts an in-built risk that extremist views succeed in this competition and subsequently undermine the system from within. In contrast, the 'substantive' view contends that no democracy must stand idly by when facing an extremist threat. Asserting that democratic essence is defined by more than a mere playing by electoral rules, the substantive view advocates the right of a democratic system to defend itself by imposing restrictions on extremist competitors.

In political practice, the German Basic Law is considered an incarnation of the substantive conception of democracy. Marked by the traumatic experience of National-Socialism, the constituents of the young Federal Republic created a democratic system with several in-built safeguards against political extremists, known as 'militant democracy' (wehrhafte Demokratie). In academic literature, the term 'militant democracy' is employed as both a literal translation of the German 'wehrhafte Demokratie' and as classification of the relative restrictiveness with which a democracy encounters extremist political actors. In this context, party proscription is one of the most controversially discussed practices. After banning the 'Socialist Reich Party' (SRP) and the 'Communist Party of Germany' (KPD) in the 1950s, Germany came to be perceived as the normative prototype of a 'militant democracy' (Fox \& Nolte, 1995; Bourne, 2012). However, the approach towards the right-wing extremist 'Nationale Partei Deutschlands' (NPD) challenges such straightforward classification. After banning procedures in 2003 were suspended for practical reasons, the Federal Constitutional Court (hereinafter FCC or Court) dismissed a second attempt to proscribe the NPD in January 2017.

The FCC's ruling in the NPD-case and its underlying reasoning are particularly relevant for a nuanced understanding of the German approach towards political extremism. This study investigates the question as to what extent the 'wehrhafte Demokratie' scheme in Germany can still be characterised as militant in application. Based on a case study of the second NPD-banning attempt, it claims that Germany should rather be perceived as an 'immunized democracy'. While the German legislature still advocates a militant approach, the ruling of the FCC represents a paradigm shift in German party- 
banning. Contrary to its former verdicts concerning the SRP- and KPD-ban, the FCC now invokes a party's (in)capacity to realise its anti-democratic goals as a decisive criterion for whether a ban is appropriate. This confines the instrument of party-banning to severe menaces such as the Weimar scenario. In the eyes of the Court, the consolidation of German democracy in the past decades has led to a greater trust in the system to regulate itself and to contain its enemies without having to employ its sharpest legal weapon.

The first chapter of this study provides a more elaborate discussion of the concepts of 'procedural' and 'substantive' democracy, combined with a review of the different philosophical arguments in favour of either conception. This lays the ground for explaining the German concept of 'militant democracy' and the way it is entrenched in the provisions of the Basic Law. The second chapter focuses specifically on the instrument of party proscription and the way it has hitherto been applied in post-War Germany. In this context, the scholarly debate on classifying the German approach towards extremist parties will be presented. Having established the theoretical framework, the third chapter represents the study's empirical core. An argumentative analysis of the request letter and the judgment on the second attempted NPD-ban reveals a change in both the motivations for $a$ ban as well as in the evaluation of its appropriateness. Finally, the conclusion discusses the implications of these findings for the further study of democratic responses to political extremism.

\section{Theoretical Framework}

\subsection{Procedural vs Substantive Democracy}

In political philosophy, the concepts of 'procedural' and 'substantive' democracy represent different theoretical views on the characteristics of a democratic system. In essence, the difference centres around whether 'democracy' is a mere method, i.e. the organisation of popular will through free elections, or whether there is an indispensable substantive core of liberal democratic values such as the rule of law and the protection of minority rights. Thus, whether procedural or substantive liberalism is perceived as the highest good of a democratic system respectively influences the view on the principle of democratic tolerance and whether it may be limited (Fox \& Nolte, 1995, p. 14). In the face of political extremism, the relative emphasis on procedural or substantive liberalism decides which element is to be preserved at the expense of the other. Another continuum for understanding the contrast between the procedural and substantive view is the relative trust in the ability of the electorate to make an informed decision. Haupt (2008) describes the different approaches towards the unknown variable of popular will as "the struggle between permissiveness and faith in the 'good' opinions on the one hand, and weariness and distrust of judgment on the other" (p. 171).

One of the most prominent advocates of the procedural view is Joseph Schumpeter. In his seminal work "Capitalism, Socialism and Democracy", Schumpeter (1994) conceptualises democracy in purely methodical terms: "Democracy means only that the people have the opportunity of accepting or refusing the men who are to rule them" (p. 285). For this process, Schumpeter deems unrestrained electoral competition to be the most important prerequisite (p. 295). He defends the principle of democratic tolerance at all cost, acknowledging that "this may imply that people stand by patiently while 
somebody is attacking their most vital interests or offending their most cherished ideals" (p. 295). According to Schumpeter, the only legitimate way to contain political extremism is through democratic self-control. The body of voters needs to be capable of making morally and intellectually qualified decisions, so that it cannot be "corrupted by the crook and the crank" (p. 294).

Schumpeter's view of democracy as a mere method is upheld by more contemporary authors such as Brian Barry and Samuel Issacharoff. Barry (1989) clearly emphasises procedural over substantive liberalism, refusing "any constraints on the content of the outcomes produced, such as substantive equality, respect for human rights, concern for the general welfare, personal liberty or the rule of law" (p. 25). In contrast, Issacharoff's position on restraints of the democratic process is somewhat more nuanced. Following the economic analogy of a 'free market-place of ideas', he claims that "even the night-watchman state has an obligation to maintain the openness of political competition in much the same way as the state must protect the integrity of economic markets [...] from anti-competitive behaviour" (Issacharoff, 2007, p. 1414). However, Issacharoff also argues that any protective measure by the state must aim at maintaining the prospect of reversibility through free elections (p. 1415). The emphasis on reversibility suggests that he is in favour of certain restrictions on anti-democratic actors, since their potential adherence to power is likely to set an end to free elections. However, Issacharoff would probably not approve of measures as restrictive as a party ban, since exclusion from electoral competition represents itself an infringement upon the principle of reversibility.

In contrast, an early plea in favour of the substantive view on democracy can be found in John Stuart Mill's essay 'On Liberty' from 1856. Based on the analogy of slavery, he argues that personal freedom has a selflimiting attribute. As much as a person may not be free to sell himself into slavery, society may not abdicate its freedom by leaving open a legal path for anti-democratic actors to gain control over it (Mill, 1962, p. 236). The contemporary philosopher John Rawls has found a similar self-limiting quality to be entrenched in the principle of tolerance, which he subordinates to justice as the ultimate aim of any democratic system (2003, p. 172). Regarding the democratic paradox of whether or not to 'tolerate the intolerant', Rawls makes a twofold claim. First, he argues that an intolerant actor has no grounds for complaint when not being tolerated, since "a person's right to complain is limited to violations of principles he acknowledges himself" (p. 191). Second, Rawls contends that the right to impose restraints on anti-democratic actors may only be exercised when facing a serious threat to societal order (p. 192). In principle, Rawls prefers natural over forceful democratic self-preservation: "Knowing the inherent stability of a just constitution, members of a wellordered society have the confidence to limit the freedom of the intolerant only in the special cases when it is necessary for preserving equal liberty itself" ( $p$. 193). He even claims that the democratic process is likely to have a positive effect on the intolerant, socialising them into accepting the right to free speech (p. 192). Regarding this point, Rawls disagrees with Karl Popper (1966) who has a somewhat more pessimistic and radical attitude towards anti-democratic actors. While Popper (1966) holds a broadly similar view on the limitedness of democratic tolerance, he even demands a right to forceful defence since he deems it unlikely that the intolerant will accept any non-violent form of confrontation: "[I]f we are not prepared to defend a tolerant society against 
the onslaught of the intolerant, then the tolerant will be destroyed, and tolerance with them" (p. 668).

In political history, the most memorable destruction of a regime by intolerant political actors was the erosion of the Weimar Republic by Adolf Hitler and his National-Socialist party NSDAP. The conception of the Weimar constitution followed a purely procedural view on democracy, which Loewenstein denounced as "exaggerated legalism" (1938, p. 602). The validity of a legislative act depended exclusively on whether it was enacted via the formal legal route. According to Schmitt (2000), this is the reason why Hitler could excavate the Weimar democracy from within "by making legal use of its own weapons" (p. 150). When Hitler's NSDAP gained a plurality of the votes in 1932 , the crisis-torn Weimar Republic had already for some time been governed by appointed 'presidential cabinets'. The latter were based on Art. 48 of the Weimar constitution, allowing for governance through so-called 'emergency decrees' that also permit the suspension of certain fundamental rights. When Hitler was appointed chancellor in 1933, he made use of this provision to enact legislation such as the 'Reichstag Fire Decree' that enabled him to legally prosecute his political enemies (Dülffer, 1992, p. 38). The extent of pressure and violent threats exercised by the NSDAP eventually forced the German parliament to virtually disempower itself and vest all legislative power in Hitler (Schmitt, 2000, p. 150).

Regarding post-War Germany, the 'trauma of Weimar' is held to have been a crucial factor in creating the Basic Law according to the concept of a 'wehrhafte Demokratie' (Miller, 2010, p. 372), commonly translated as 'militant democracy'. The literature on political extremism uses the term 'militant' interchangeably as literal translation of the German word 'wehrhaft' and as a normative concept denoting the degree of radicalism with which a system approaches political enemies. While this represents an unfortunate lack of academic rigour, it is indeed difficult to find a proper English translation of the term 'wehrhaft'. Alternative terms like "vigilant" (Schmitt, 2000, p. 150) or "watchful" (Pedahzur, 2004, p. 109) appear too weak in that they merely evoke the notion of awareness and surveillance of political enemies. In order to prevent linguistic and conceptual confusion, this study suggests the term 'selfdefending democracy' as a more accurate translation of 'wehrhafte Demokratie'. In what follows, 'self-defending democracy' will be employed for describing the German conception of democracy, referring not to its governmental system but to "the course chosen by a democracy in its efforts to protect itself" (Pedahzur, 2004, p. 111). In contrast, the term 'militant democracy' is used exclusively in reference to the relative restrictiveness of this course in political practice.

The German 'self-defending democracy' scheme is built on five main provisions within the Basic Law that allow the system to restrict its political enemies (Haupt, 2008, p. 178). Art. 79(3), also known as 'eternity-' or 'perpetuity-clause' (Pedahzur, 2004, p. 117), can be perceived as a basic insurance against totalitarian overthrow in that it precludes the possibility of altering basic principles of German democracy even by constitutional amendment (Basic Law, 2014, p. 19). Furthermore, Art. 9(2) allows to restrict the freedom of association, while Art. 18 provides for the possible forfeiture of an individual's basic rights in case of severe abuse (Basic Law, 2014, p. 2; p. 5). However, Art. 20(4) also provides for an individual right of resistance against attempts to overthrow the constitutional order. Finally, Art. 21, which 
is also known as the 'party privilege clause' (Haupt, 2008, p. 175) allows for the proscription of political parties. Although the notion of 'privilege' might appear somewhat erratic in this light, it stems from the fact that the first paragraph of Art. 21 emphasises the special role and importance of political parties in German representative democracy. Contrary to other associations, political parties may also not be banned directly by the executive. While the latter as well as the German parliament may request a ban, Art. 21(2) accords the right to decide on a party's unconstitutionality exclusively to the judiciary, i.e. the Federal Constitutional Court.

According to the Basic Law, the kinds of parties that may be banned are those that "by reason of their aims or the behaviour of their adherents seek to undermine or abolish the free democratic basic order or to endanger the existence of the Federal Republic of Germany" (Basic Law, 2014, p. 6). The notion of 'free democratic basic order' refers to the ensemble of fundamental values entrenched in the German constitution, including "the enumerated human rights, sovereignty of the people, separation of powers, government accountability, the legality of the executive, judicial independence, and the multi-party system, including the right to form and exercise opposition" (Haupt, 2008 , p. 179). While actions that go against an individual characteristic of German democracy are deemed anti-constitutional (verfassungsfeindlich), only an outright opposition to the entirety of the 'free democratic basic order' renders a party unconstitutional (verfassungswidrig) and justifies a ban (Pedahzur, 2004, p. 109).

\subsection{Party-Banning in Germany}

The German history of party banning has received much scholarly attention in the field of political extremism. Thus far, the FCC has outlawed two parties as unconstitutional, both in early post-War Germany. The proscriptions of the SRP in 1952 and the KPD in 1956 are characterised by Jesse (2001) as symbolic cases where "a still fragile democracy wanted to demonstrate its strength" ( $p$. 685 ). The unconstitutionality of the SRP was justified mainly on the grounds of its affinity towards the NSDAP, both in terms of organisational and programmatic characteristics. The FCC found the SRP to be organised according to the National-Socialist 'Führerprinzip', concluding that an undemocratic internal organisation reflected the party's aim to implement the same structures on a state level (FCC, 1952, para. 216). Furthermore, ideological parallels with National-Socialism were deemed sufficient to establish the aim of abolishing the free democratic basic order (para. 322).

As a communist party, the KPD represented the ideological opposite of the SRP. However, Issacharoff explains the link between them through the fact that "both parties had ties to totalitarian ideologies and both emerged at a time of real vulnerability for West Germany" (2007, p. 1433). The KPD-ban represents a delicate case in which the FCC both limited and extended the scope of Art. 21(2). On the one hand, it held that merely refusing the fundamental principles of the free democratic basic order is not sufficient to establish unconstitutionality. Instead, "[a] party has to be actively combative and aggressive towards the existing order, and acting in accordance with a fixed plan with the ultimate goal to abolish the existing order" (FCC quoted in Haupt, 2008 , p. 179). On the other hand, the Court asserted that a party may be banned even if the realisation of its unconstitutional goals was improbable - a 
mere 'logical danger' was deemed sufficient (p. 179). Thus, the KPD-ruling gives Art. 21(2) a clearly pre-emptive character in that it allows for banning a party on the sole ground of its ideology, irrespective of whether it presents an actual threat to German democracy.

After not having invoked party-banning procedures for four decades, the German legislature and executive launched a joint petition for banning the extreme-right 'Nationale Partei Deutschlands' (NPD) in 2001. This demand for proscription is best perceived in the context of an increase in extreme-right motivated terrorist acts and violent assaults after German reunification (Haupt, 2008 , p. 173). After initially allowing the proceedings, the FCC dismissed the case in 2003 on the grounds that the NPD's senior level was infiltrated by a large number of undercover-agents from the 'Federal Office for Constitutional Protection'. While covert investigations of political parties are not illegal in themselves, the Court held that these circumstances rendered it impossible to assess whether the NPD's self-defined ideology was in fact unconstitutional (Minkenberg, 2006, p. 25).

The demand and motivations for banning the NPD in the first place have attracted extensive scholarly attention. After its biggest successes in the 1960 s where it almost surpassed the five percent threshold for entering the German Bundestag, the NPD had developed into a marginal party in terms of both membership and electoral support by 2001 (Mudde \& Backes, 2000, p. 467). Furthermore, the NPD is generally perceived as an agent of the 'new radical right' (Kitschelt, 1995), not refusing representative democracy as directly as totalitarian parties in the inter-War and immediate post-War times (Capoccia, 2001, p. 433). In this regard, the demand for banning the NPD does not fit the original rationale behind the German provision for party proscription, which Bligh (2013) names the 'Weimar paradigm' (p. 1325). He perceives the NPD-case as a manifestation of a new trend in party-banning, targeting those that neither overtly promote anti-democratic goals, nor stand a chance of coming to power and eroding the democratic system (p. 1326).

Bligh groups the NPD into the first of three categories for recent cases of party-banning in Europe: parties inciting hate and discrimination, parties supporting violence and parties threatening a state's identity. He argues that the banning of parties falling into one of these categories is better understood under a so-called 'legitimacy paradigm' (p. 1358). Bligh explains that over the past decades, political parties and the democratic state have become more closely linked to one another. In contrast to an almost hostile relationship in the $19^{\text {th }}$ and $20^{\text {th }}$ century, the crucial role of parties in connecting state and society has become officially recognised and sometimes even constitutionally entrenched (see the 'party privilege' clause in the Basic Law). Through the provision of public funding and prioritised media access, the state awards an a priori legitimacy to the opinions and values promoted by political parties ( $p$. 1358). Hence, a state threatens to lose its democratic face when a party's actions or statements contradict liberal values, e.g. by promoting xenophobic and anti-pluralist attitudes. In this context, a ban is invoked for removing the 'stamp of legitimacy' that the party-status imprints upon a political actor in the public's eyes (p. 1362).

While the NPD's perception as a "party inciting hate and discrimination" (Bligh, 2013, p. 1339) represented the motivation for the attempted ban, scholars such as Jesse and Minkenberg judge a ban as an inappropriate means to the end of curtailing right-wing violence in Germany. Jesse (2001) holds that 
a proscription of the NPD would neither eliminate a vital threat to the German state - since there is none - nor would it effectively combat xenophobic violence (p. 688). The latter is considered a structural problem in Eastern Germany, where informal groupings such as Neo-Nazi 'Kameradschaften' are held to be much more influential than the NPD (Henkel \& Lembke, 2001, p. 576). Minkenberg (2006) agrees with this view, also pointing out potentially negative effects of a ban. He argues that following a ban, the party's supporters are likely to radicalise even further and reorganise themselves in undergroundassociations which are much more difficult to control for the state (p. 37).

However, the fact that the NPD-case of 2003 has not been judged on substantive grounds makes it difficult to draw conclusions as to whether German democracy has maintained its 'militant' attitude from the 1950s. Thus, the two successful instances of party proscription represent the hitherto main criteria for classifying the German approach towards extremist parties in the academic literature. In their seminal work "Intolerant Democracies" (1995), Gregory Fox and Georg Nolte categorise democratic states along the lines of a 'procedural vs substantive' theoretical approach and a 'passive vs militant' practical approach towards extremism. Highlighting the fact that neither the SRP nor the KPD had engaged in political violence and was banned nonetheless, the authors consider Germany as an example of a 'militant substantive' democracy (p. 33). Moreover, the doctrine established in the KPD-case that a party does not need to constitute an imminent threat for the state is emphasised as further proof of German 'militancy' in the face of extremist parties (p. 33).

More recently, Bourne (2012) has established another, three-level qualification of responses to political extremism along the dimensions of 'procedural vs substantive', 'abstentionist vs activist' and 'tolerant vs intolerant' democracies (p. 208). Regarding the classification of Germany, she reaches a content-wise similar conclusion as Fox \& Nolte by categorising it as 'substantive-activist-intolerant' (p. 208). Bourne's characterisation of German democracy as activist and intolerant is also based on the KPD-verdict that allows parties to be banned for both anti-system behaviour and anti-system ideology, regardless of a practical threat. Regarding the NPD-case, Bourne considers the mere attempt to ban the NPD as evidence for a continuing pattern of a militant approach towards extremist parties, irrespective of its outcome ( $p$. 211).

In contrast, Ami Pedahzur (2004) reaches a more differentiated judgment regarding whether the German 'self-defending democracy' is also to be qualified as normatively 'militant'. He takes the notions of 'militant' and 'immunized' as two ends of a scale that allows for measuring the scope and intensity of actions taken by a state against its political enemies ( $p$. 115). Pedahzur depicts the difference between a militant and an immunized approach by describing extremism in analogy to an illness (p. 116). The militant route implies a treatment of extremist symptoms with the strongest medication available, which is likely to cause the side-effect of compromising of core democratic principles such as fundamental rights or freedom of speech. In contrast, the immunized approach rather focuses on preventing the illness's outbreak through a strengthening of civil society, while more intrusive legal remedies are only employed when the democratic body's immune system cannot cure the illness on its own (p. 116). Regarding the legal-judicial dimension which includes party proscription, he deems Germany to be 
"approaching the immunized route" because the radical remedy of a ban has only been successfully applied twice and any future banning attempt would need to undergo thorough proceedings before the FCC (p. 120).

In this context, a new attempt for banning the NPD launched in 2013 represents a promising case for re-examining whether the German approach towards extremist parties can still be classified as 'militant'. Prior to the 'covert agent scandal' that led to the dismissal of the first banning attempt, Jesse (2001) denotes that although launching a banning petition against the NPD was inappropriate, a ban itself would be lawful. He claims that while the NPD is incapable of infiltrating German democracy with its anti-democratic ideology, the fact that a ban was nonetheless requested almost prescribes a positive ruling. Since the 'logical danger' doctrine established in the KPD-case does not warrant a realistic threat and the NPD clearly displays the required "activecombative attitude" against the democratic order, Jesse holds the conditions for a ban under Art. 21(2) to be fulfilled (p. 693). He argues that although the banning petition was an instance of disproportionate political activism in the first place, a negative ruling of the FCC would be an equally problematic way of correcting political errors via the judicial route (p. 694). According to Jesse, not banning the NPD would "seal the faith of a generally extenuated conception of 'self-defending democracy'"' (p. 695).

In light of Jesse's argumentation, it appears controversial that the FCC denied a proscription of the NPD on 17 January 2017. Suggesting a change of course, the second NPD-case warrants closer examination. Due to the recentness of the verdict, the case has not yet been evaluated in scholarly literature. This study attempts to fill this gap through an argumentative analysis of the second NPD-ban proceedings, in order to reveal the contemporary interpretation of the German 'self-defending democracy' scheme. First, the arguments presented in the request letter of the claimant (i.e. the Bundesrat, the legislative body representing the different Länder-governments on a federal level) are briefly analysed in order to understand how the German legislature interprets the 'self-defending democracy' scheme. Second, the FCC's judgment is examined in detail regarding changes and controversies in its arguments for denying the NPD-ban. Taken together, these analyses allow for assessing the development and current state of German 'self-defending democracy' and whether its classification as 'militant' is still appropriate. Since both the request letter and the judgment are written in German, all quotes derived from these sources were translated into English by the author of this paper.

\section{The second NPD-Banning Proceedings}

The second petition to ban the NPD was launched by the German Bundesrat in 2014. A closer look at the request letter shows that the attempted NPD-ban is not motivated by the original reasoning behind the German provision for partybanning, i.e. the Weimar-scenario of a party that threatens to overthrow the democratic state. Instead, the concerns of the Bundesrat pertain to the paradox that a party like the NPD can engage in unconstitutional action under the seal of constitutional legitimacy. While the Bundesrat recognises that the NPD is a marginal party in terms of membership and electoral support (Bundesrat, 2014, 
p. 27), it deems the mere legality of this extreme-right organisation to be "a disturbing phenomenon that impedes trust in the constitutional state" (p. 7). Claiming that the 'party privilege' should not protect the NPD in its pursuit of anti-democratic goals (p. 8), the Bundesrat clearly follows the reasoning behind Bligh's concept of a 'legitimacy paradigm' in its motivation for banning the NPD. The Bundesrat establishes the NPD's alleged unconstitutionality based on both the party's ideology and its actions. It identifies four main elements that contradict the free democratic basic order (p. 169). First, the NPD's conception of a 'popular community' that denies certain basic rights to all non-ethnic Germans is held to infringe upon the principle of human dignity (p. 169). Second, the Bundesrat finds that the NPD refuses representative parliamentarism as the German form of democratic government. It substantiates this claim by invoking quotes from party officials such as Matthias Heyder, who stated that "We do not intend to enter the parliaments in order to become part of this system. [...] This is a cold, concreted, hostile and asocial system. It doesn't need to be changed, it needs to be abolished!" (quoted on p. 46). Third, the request letter of the Bundesrat provides a lot of evidence for the NPD relativizing Nazi-crimes and glorifying the Third Reich by using its vocabulary, songs and general symbolism (p. 184). Fourth, the Bundesrat takes a number of hate crimes and violent assaults committed by the party's adherents or in the context of its events as proof that the NPD disregards the state's monopoly on violence (p. 197).

Providing a large amount of mostly unambiguous evidence for the NPD's unconstitutionality, the Bundesrat advocates a rigorous application of the party-banning provision in this case. Emphasising that Art. 21(2) has a clearly preventive character, the Bundesrat justifies the permissibility of its banning request with the KPD-doctrine that no concrete, but merely a 'logical danger' is required for a ban (p. 102). However, the Bundesrat also demonstrates awareness of the ambivalence inherent in a party ban, questioning its consequences and potential negative impacts:

Given that it is far from reaching its unconstitutional goals, wouldn't a proscription of the defendant be too harsh of a sanction? Isn't the strength of a democratic state rather displayed in its critical ignorance of such political activities, as long as they have not crossed a certain threshold of threat? ( $\mathrm{p}$. 242).

Eventually, the Bundesrat nonetheless follows the motto of 'nipping things in the bud', concluding that its request to ban the NPD can be considered suitable, proportionate and necessary. It argues that a ban would fulfil the purpose of preventing a party from pursuing unconstitutional goals while being protected by the 'party privilege' (p. 228). At the same time, a ban is considered necessary because the 'party privilege' does not allow for milder measures, such as cutting off state funding, which would artificially disadvantage a party in electoral competition. Finally, the Bundesrat justifies the request as appropriate since a ban of the NPD would be embedded in a more holistic approach of fighting right-wing extremism, including educational and civil society initiatives (p. 229).

In this light, it calls for "making full use of the available legal means to avoid giving unconstitutional activities a legitimate public platform" (p. 7). Thus, the Bundesrat interprets the German 'self-defending democracy' scheme 
in a fairly militant way. It advocates a similarly strict application of Art. 21(2) as in the former two banning cases, albeit for different reasons. Its main concern seems to be that a more lenient approach towards the institutionalised extreme-right, notably in form of an official party, represents a wrongful form of tolerance that would damage the image of German democracy.

The FCC issued its judgement on the second NPD banning proceedings on 17th January 2017. The document is divided into four parts. First, the Court documents the judicial process up to the official trial in part $A$ and affirms the permissibility of the proceedings in part $B$. These parts are of a formal and procedural character and will therefore not be analysed. Since this study's focus is on the substantive ruling of the Court, the relevant parts of the judgment are parts C and D. In part C, the FCC establishes the general scope and legal doctrines for the German party-banning provision, which are subsequently applied to the case of the NPD in part D. This two-part division is also suitable for this analysis, since it allows to reveal both the Court's current general interpretation of 'self-defending democracy' as well as its assessment regarding whether the NPD in particular demands the use of its strictest measures.

In part $C$ on the general legal criteria, the FCC takes a very nuanced and balanced position on the German norm for party proscription. On the one hand, it expresses clear commitment to the practice of party banning in general and justifies the existence of Art. 21(2) by asserting that it does not stand in contrast to democratic principles. For instance, the FCC (2017) explains that the apparent paradox of "protecting liberty through the limitation of liberty" ( $p$. 138) does not contradict the principle of free will formation. The Court considers the possibility of imposing limitations as crucial for the permanent establishment of a democratic order, making free will formation possible in the first place (p. 138). Similarly, the FCC argues that party proscription also does not contradict the principle of popular sovereignty, since a truly liberal framework is needed for that very principle to unfold in practice (p. 139). Furthermore, the Court emphasises that Art. 21(2) does not represent a postWar emergency provision that has since lost its purpose or validity. It clarifies that the rationale behind the German provision for party-banning stems from the Weimar experience and is also primarily designed "[...] to prevent a repetition of the catastrophe of national-socialism and the destruction of the Weimar Republic" (p. 137). At the same time, the Court holds that Art. 21(2) constitutes a permanent structural component of the German 'self-defending democracy' scheme, also suitable as a contemporary means for encountering parties with unconstitutional goals and their possibilities for political action ( $p$. 137).

On the other hand, the Court relativises its general commitment to Art. $21(2)$ by acknowledging that despite the greater goal of protecting a democratic system, party banning represents a heavy intrusion into the process of democratic will formation (p. 137). It characterises the provision as a "democracy-curtailing, exceptional norm" (p. 141) and as "the sharpest and most double-edged weapon of democracy" (p. 158). The FCC emphasises the need to interpret the single elements of the offense restrictively in order to ensure that a party ban does not take the form of an "attitude- or world-viewproscription" (p. 154). To this effect, the FCC limits an infringement of the 'free democratic basic order' to its most indispensable features (p. 144). Regarding the new, contemporary motivations for party banning such as a party's support of violence and the creation of a 'climate of fear', the Court also positions itself 
rather cautiously. It holds that a party's actions must be objectively suitable to create a 'climate of fear'. A subjective threat perception is deemed insufficient (p. 158). Furthermore, concrete actions and particularly criminal offenses committed within such climate need to be unambiguously attributed to the party in question (p. 152). The Court's way of arguing displays that it considers the notion of a 'climate of fear' as legally 'weak' and too vague for providing sufficient evidence for the banning of a party.

After discussing the general challenges and controversies related to a party ban, the Court reflects on the legal doctrines established in the past two instances of party proscription. Regarding the SRP-case, it reaffirms its banning decision and does not engage in an express derogation. However, it finds as a general criterion that "the mere affinity to National-Socialism is insufficient for establishing the offense under Art. 21(2)" (p. 159). While the Court had recognised this criterion in a similar way in the SRP-case, the judgment as well as the secondary literature on it reveal that the ban was in fact exclusively based on the party's parallels to the NSDAP regarding organisational structure, membership and ideology (FCC, 1952, para. 216; para. 322). Apart from its proximity to the NSDAP, the SRP was a marginal party similar to the NPD that, moreover, was not connected to any forms of political violence (Jesse, 2001, p. 684). As it will be explained below, ideological proximity to National-Socialism does not represent the crucial criterion in the Court's decision on the NPD-case. Thus, one can perceive a derogation from the SRP-case not de jure, but de facto in that the criterion of affinity to NS-ideology seems to have lost prominence for the Court.

The FCC's position towards the KPD-verdict proves significantly more complex and controversial. On the one hand, it confirms its ruling regarding both the need for an 'active-combative aggressive attitude' and the 'logical danger' doctrine. The FCC emphasises that the wording, historical provenance and purpose of Art. 21(2) would be contradicted if a party needed to represent a concrete danger for being banned. Based on the historical experience that "radical strands are harder to fight the more they gain ground" (p. 157), the Court reaffirms that Art. 21(2) has a clearly preventive character. However, the Court subsequently limits the scope of a 'logical danger', stating that the exceptional character of party proscription requires "concrete and weighty evidence that the party's unconstitutional actions have a realistic chance of being successful" (p. 158). Here, the Court initiates a paradigm change in the application of Art. 21(2). It explicitly derogates from the generous guideline established in the KPD-case that a party may be banned "even if it does not appear humanly possible that the party is capable of realising its unconstitutional goals in the foreseeable future" (p. 158).

The Court has thus established a new legal doctrine for evaluating whether the partial offense of 'actively seeking to' abolish the free democratic basic order is fulfilled (see p. 158, para. 585). Under the name of 'potentiality', the Court in fact introduces the 'probability question' (Bligh, 2013, p. 1372), a criterion that has generally been deemed important to the evaluation of party bans and whose absence in Germany contributed to its assessment as 'militant'. However, Bligh (2013) explains that the 'probability question' is only relevant to and useful for banning-cases that reflect a Weimar-scenario (p. 1372). Since contemporary motivations for party-banning such as the creation of a 'climate of fear' represent more abstract aims that are at best indirectly related to regime overthrow, he concludes that "the probability question loses its value 
as a limiting factor under the 'legitimacy paradigm'" (p. 1372). In this regard, the FCC's approach appears paradoxical. While it had expressly refrained from asking a probability question in the SRP- and KPD-cases that were clearly marked by the fear of a Weimar-scenario, this criterion is now introduced in a case against a party that was launched out of fundamentally different concerns, i.e. about democratic legitimacy.

However, one can make sense of this paradox when perceiving it as a change in the relative militancy that the Court deems appropriate for the application of the 'self-defending democracy' scheme. The SRP- and KPD-cases were first and foremost symbolic instances where a young and fragile German democracy wanted to demonstrate its self-defending capacity (Jesse, 2001, p. 625; see also Issacharoff 2007). Since both parties were far from presenting an electoral threat - the KPD even more so than the SRP - and did moreover not display violent behaviour, asking the 'probability question' would most probably have precluded a ban. Thus, the Court's decision for a more generous interpretation of Art. 21(2) can be considered a conscious choice for a militant approach towards extremist parties, at the expense of legal and political correctness.

Along the same lines, the change in course in the NPD-case represents a conscious decision to confine Art. 21(2) primarily to Weimar-scenarios and to restrict its application for 'softer' threats of parties that only create conflicts of legitimacy. Contrary to the Bundesrat, the Court seems to perceive a greater damage to the image of German democracy in an overly generous use of partybanning than in the legal existence of an extremist party like the NPD. In this regard, establishing a 'potentiality doctrine' does not represent a purely judicial step, but also contains a political statement. However, it would be overhasty to characterise the Court's approach as a bold form of legal policy-making. First, the revision of guidelines for interpreting Art. 21(2) lays within the Court's mandate of "considering the provisions of freedom and value decisions within the Basic Law and putting them in proportion to the protective purpose of Art. 21 (2) to ensure the greatest possible accordance" (FCC, 2017, p. 163). Second, Bligh (2013) admits that there is one scenario under the 'legitimacy paradigm' where a probability question could be useful: "[...] when the parties are so insignificant that they could not pose any actual danger" (p. 1372). Given this background, this analysis continues to examine how the FCC applies the ensemble of its old and new legal criteria for party-banning to the case of the NPD.

In part $D$ of its judgment, the Court generally deems the offense of Art. $21(2)$ to be fulfilled by the NPD. It largely follows the Bundesrat's line of arguments when establishing the party's unconstitutional character based on three main elements. First, the Court holds that the NPD's purely ethnic conception of the German people infringes upon human dignity, since it denies equal rights to all German citizens that do not belong to the ethnic community in the strictest sense. The FCC (2017) emphasises that the 'German people' is essentially defined through citizenship: "The Basic Law does not recognise a notion of 'people' that is exclusively oriented on ethnic categories" (p. 186). Second, the Court finds that the NPD's popular conception contradicts the basic right to equal participation in political will formation and the principle of popular sovereignty. In addition, the NPD's vision for the German state is also held to infringe upon the democratic principle. Based on publications and statements by NPD-officials, the FCC concludes that the party aims at dismantling 
representative, parliamentary democracy and replace it with an authoritarian nation-state following the model of the German Reich (p. 201).

Third, the NPD's affinity to NS-ideology is invoked as a strong indication for the party's anti-democratic character. However, as mentioned above and contrary to the SRP-case, proximity to National-Socialism is treated by the Court merely as one evidentiary criterion among others to assess the party's unconstitutionality. The FCC enumerates a number of instances where NPDmembers or officials glorified NS-personalities and denied their crimes. Towards the latter, it displays a particular sensitivity. Statements of NPD-officials like "[ $\mathrm{t}]$ he historical truths are prosecuted, discredited as revisionism or holocaustdenial, and relativisation of NS-crimes is punished with incarceration" (quoted on p. 216) are cited as proof that the NPD disregards the German 'Erinnerungskultur' (culture of rememberance), being one of the Basic Law's highest subjects of protection (p. 216). Based on these three findings, the Court judges the NPD's ideology as prima facie unconstitutional. Finding that the NPD not only aims at 'undermining', but 'abolishing' the free democratic order, the FCC unmistakably expresses that it generally considers the NPD to be an antidemocratic party (p. 219).

In that light, the sudden change in the FCC's argumentation comes as a surprise. Despite its unconstitutional goals and their systematic pursuit, the Court concludes that the NPD's conduct nonetheless does not fulfil the partial offense of "seeking to [abolish]" the basic order (p. 233). It bases this conclusion exclusively on the fact that a realistic potentiality of success is not given (p. 233). Given the amount of unambiguous evidence previously mentioned by the Court, it might appear somewhat construed and inconsistent that a dismissal of the NPD-ban is based on a single criterion. However, its subsequent argumentation reveals that in applying the potentiality doctrine, the Court engages in a holistic and differentiated evaluation of the NPD's relative position in contemporary German democracy.

The FCC has established three criteria for assessing potentiality of success: First, the situation of a party regarding membership, organisational structure and scope of mobilisation; second, its scope of societal impact as defined by election results, supporting networks and representation in public office; and third, a party's extra-political means, strategies and other conclusive circumstances (p. 158). In applying these criteria to the current state of the NPD, the Court concludes that it is neither possible for the party to realise its goals through the democratic will formation process, nor can it be found to undermine this process (through criminal means) to a sufficient extent (p. 233). According to the Court, imposing its unconstitutional goals through parliamentary means is excluded because the NPD is not able to reach a majority neither via election results, nor via a coalition. It recalls that the NPD never managed to enter the German Bundestag and, according to the evidence provided by the Bundesrat itself, also displays a downwards tendency in electoral support on the Länder-level (p. 234).

Moreover, the FCC emphasises the decline in NPD-membership from 28,000 in 1969 to a mere 5,066 in 2014 (p. 237). It refers to a 2014 report by the Federal Office for Constitutional Protection, stating that the NPD suffers severely from inner-party conflicts, financial problems and the impact of a looming ban (p. 238). Interestingly, the Court quotes Jesse, who acted as authorised expert in the proceedings, in claiming that "the NPD is an isolated, ostracised party whose ability of campaigning - if one can even speak of such 
- has declined over the past years" (p. 238). Following this, the Court concludes that the NPD has an overall insignificant impact on German society. The FCC's argumentation reveals that it considers the few extreme-right dominated villages in the Eastern Länder, invoked by the Bundesrat as proof for the NPD infiltrating civil society, as systemic errors that can occur in any democratic state (p. 244).

In contrast, the FCC rather praises the general immunity of German society towards the anti-democratic agitations of the NPD. It recognises that any NPD-demonstration is usually accompanied by a much more numerous counter-demonstration, organised by civil society initiatives against right-wing extremism (p. 239). Moreover, the Court invokes findings that whenever the NPD's responsibility for an event is clearly visible, this significantly reduces the number of participants (p. 242). The FCC's argumentation shows that by introducing the potentiality doctrine, it has found an intelligent way of including into party-banning considerations the state of German democracy as a whole and the relative impact of the respective party. In this regard, the Court's judgment resembles a sociological assessment that displays trust in German society to contain the NPD on its own through both electoral and civil means. This shows that the ultimate guardian of the 'self-defending democracy' scheme no longer interprets and applies it in a militant way. Recalling Pedahzur's scale from militant to immunized approaches towards political extremism, it appears that German democracy is approaching the latter end of the continuum.

This assessment is largely confirmed when looking at how the Court evaluates the NPD's potentiality of success through extra-political means. While it has followed a socio-political line of argumentation for assessing the NPD's political prospects, the FCC's claim that there is no sufficient evidence that the party realises its goals through violence and criminal offenses is derived from a strict interpretation of the law (see p. 248). The Court holds that number, subject and gravity of the offenses named in the request letter are insufficient to establish a general tendency of NPD-supporters to disregard the state's monopoly on violence (p. 249). Furthermore, it recalls that for being able to invoke certain crimes as evidence against the NPD in the banning proceedings, the former need to be unambiguously attributed to the party. The Court finds that in many cases, this is not possible, either because the offender was not identified or the offense was just committed in the broader context of an NPDevent (p. 250). It emphasises that as such, the organisation of and participation in political events, e.g. demonstrations against asylum seekers, represent "legitimate means within the political opinion-battle" (p. 257).

Moreover, the FCC claims that no direct causal relationship can be established between the NPD and the presumed 'climate of fear' in certain Eastern German areas. The Court recalls that according to political experts such as Jesse, the NPD does not have a leading role within German right-wing extremism and is arguably even less influential than the informal Neo-Nazi 'Kameradschaften' (p. 243). Furthermore, it judges the threat of NPD-members towards people living in extreme-right dominated areas to be a subjective perception, since the former have thus far not committed an unambiguously attributable offense against them (p. 258). Strikingly, it also claims that a call of former NPD-parliamentarians addressed to the party's supporters to go for an "open day at the refugee home" (quoted on p. 259) could be considered as permissible use of parliamentary control rights. Regarding the unmistakably threatening rhetoric employed by NPD-supporters on this and many other 
occasions, the FCC's strict adherence to a purely legal interpretation of the facts appears borderline legitimate.

One might argue that by emphasising legal correctness in the face of racist threats and intimidation, the FCC does not live up to its responsibility of protecting the German people. However, the Court's strict adherence to the law can also be considered further proof for the development from a militant to an immunized interpretation of German 'self-defending democracy'. Weighing the vulnerability of a small number of people against the overall damage that a party ban would do to the values of liberal democracy, the Court concludes that aggressive threats emanating from single NPD-supporters are more effectively combatted through police and criminal law (p. 263). Its argumentation reveals that the Court considers a 'climate of fear' as overly abstract and the NPD as too insignificant for making use of a party ban. In this regard, the potentiality doctrine represents a way for the FCC to make a political statement within the boundaries of its legal mandate. Contrary to Jesse's earlier claim, the denial of an NPD-ban should not be considered a wrongful form of legal activism. The Court's judgment is better perceived as expressing faith in an immunized German democracy that does not need to invoke its sharpest weapons against a party as marginal as the NPD.

\section{Conclusion}

This study has investigated the question as to what extent the interpretation and application of the German 'wehrhafte Demokratie' scheme can still be characterised as 'militant'. After explaining the philosophical and historical foundations of the German approach towards political extremism, the latter was reconceptualised as 'self-defending democracy' due to the ambiguous use of the term 'militant' in academic literature. Subsequently, the study focused on the practice of party-banning under Art. 21(2) of the Basic Law. The bans of the national-socialist SRP and the communist KPD in the 1950 s were discussed regarding their generous interpretation of Art. 21(2) and the resulting general perception of Germany as a 'militant democracy'. However, a subsequent case study of the second NPD-banning attempt has revealed that notably the 2017 FCC-judgment, denying the party's proscription, renders previous academic classifications of Germany as 'substantive-militant' or 'activist-intolerant' largely inaccurate.

While the Bundesrat still displays a militant attitude in its request for an NPD-ban, the FCC as ultimate guardian of the 'self-defending democracy' scheme has moved towards a more cautious and restrictive interpretation of Art. 21(2). By introducing the 'potentiality' question, the FCC explicitly derogates from its ruling in the KPD-case. This new legal doctrine requires concrete evidence that in addition to an unconstitutional ideology, the party under consideration has a realistic chance of being successful in implementing this ideology in political practice. With the 'potentiality' doctrine, the Court has thus introduced an additional safeguard against the disproportionate application of party bans. Its denial of an NPD-ban can be taken as an indication that Germany has developed from a militant to a largely immunized approach towards political extremism. Expressed along the lines of Pedahzur's medical analogy, the FCC no longer perceives a need for employing strong antibiotics 
against the minor and local harm caused by the NPD, hardly representing more than a cold from the broader perspective of a consolidated democratic body. Moreover, the new potentiality doctrine in fact precludes the success of any 'modern' party-banning request motivated by concerns about democratic legitimacy. In a German democracy as stable as to date, the FCC confines Art. $21(2)$ to the event of a serious threat and denies that its applicability may be stretched to the new trend in party-banning under the 'legitimacy paradigm'. The Court displays due awareness and sensitivity towards historical experiences, while at the same time acknowledging that a democracy's capability of self-defence extends beyond legal means. In this light, it appears unlikely that any German party will be banned in the near future.

The Court's approach is particularly expressive considering that democratic regimes increasingly resort to practices such as surveillance and prolonged states of emergency, compromising democratic principles and diminishing people's trust in the system. In contrast to such restrictive practices, the FCC emphasises the self-supporting features of democracy. It asserts that the democratic core values represent strong enough cornerstones to protect the system from becoming unhinged in the face of an extremist fringe party. The NPD-judgment displays commitment to a truly liberal democracy, thus sending a positive message about the stability and trustworthiness of a democratic state in times where the latter are often accused of illiberal practices.

However, it needs to be acknowledged that this study's re-classification of Germany as an 'immunized democracy' is exclusively based on a change in the practice of party-banning and the attitude of the FCC. This claim needs to be substantiated through further analyses of whether the organs of German democracy have also become more cautious in the banning of political associations or more generous in authorising extremist demonstrations, which has been remarked in the literature as another manifestation of German militancy. For a more holistic picture of the current state of German democracy, future research would also need to focus on the amount and effectiveness of civil society initiatives and educational projects in countering political extremism. 